Cornell University Law School

Scholarship@Cornell Law: A Digital Repository

$5-2021$

Measuring the Effectiveness of the Proposal to Divest Military

Commanders of Disposition Authority for Sexual Assault Cases: A Comparative Quantitative Analysis

Brian L. Cox

Follow this and additional works at: https://scholarship.law.cornell.edu/clsops_papers

Part of the Criminal Law Commons, and the Military, War, and Peace Commons 


\title{
Measuring the Effectiveness of the Proposal to Divest Military Commanders of Disposition Authority for Sexual Assault Cases: A Comparative Quantitative Analysis
}

\section{Contents}

\author{
by Brian L. Cox*
}

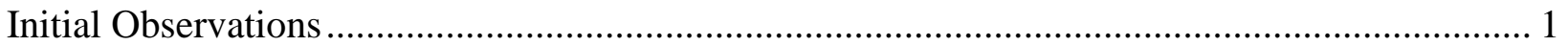

Developing the Factors by Which to Measure "Success" ............................................................ 3

Brief Introduction and Overview of Current Relevant Discourse in the Four Selected

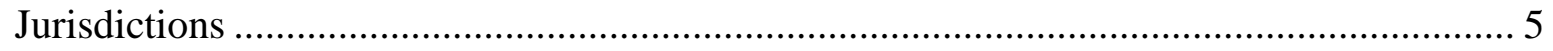

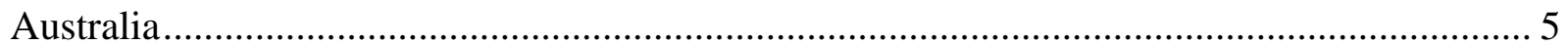

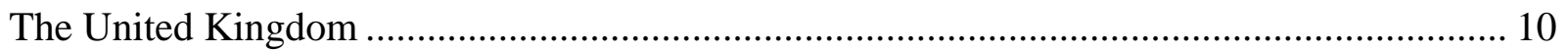

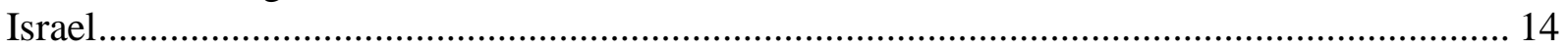

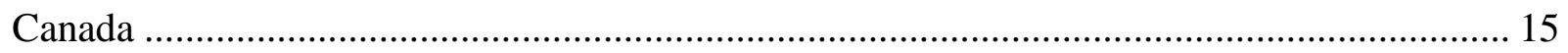

The Comparative Quantitative Analysis and the Independent Review Commission

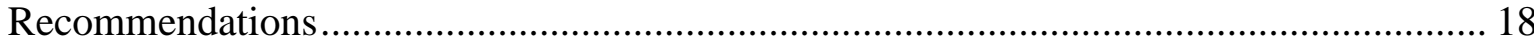

\section{Abstract}

As suggestions to modify the practice of the U.S. military justice system return to the fore of American political discourse, the perennial proposal to divest commanders of authority to convene courts-martial to adjudicate allegations of sexual assault is once again at the center of the debate. While reformists are adamant that the suggested revision would support efforts to end what has been characterized as an "epidemic of rape" in the U.S. military, the precise connection between the "reform" and the desired improved outcomes remains tenuous. An assessment of jurisdictions that have already divested commanders of such authority could provide persuasive support to the reformist assertion that the United States could expect improved performance - if the assessment reveals improved performance in other jurisdictions.

This essay conducts a comparative quantitative analysis of four jurisdictions - Australia, the United Kingdom, Israel, and Canada - to determine whether vesting court-martial convening authority in lawyers rather than commanders has resulted in improved performance in selected criteria in relation to the issue of sexual assault in the military. The comparative quantitative analysis conducted in this essay indicates that there is no correlative relationship between the "reform" and the improved performance reformists hope to achieve, at least in the context of the jurisdictions examined. This lack of a demonstrated correlative relationship in other jurisdictions creates reason to doubt whether divesting commanders of the authority to convene courts-martial to adjudicate allegations of sexual assault would lead to improved performance related to sexual assault in the U.S. military.

\footnotetext{
* (c) 2021. Adjunct professor of law, Cornell Law School; visiting scholar, Queen's Law in Ontario. In 2018, Prof. Cox retired from the U.S. Army after 22 years of military service. While in the military, Prof. Cox served as an airborne infantry soldier, combat camera operator, airborne infantry officer, and for seven years as an Army judge advocate. His combat deployments include Iraq from 2003-2004 as a combat camera operator and Afghanistan from 2013-2014 as an operational law advisor and then chief of international and operational law for Regional CommandEast. Prof. Cox also served as a military prosecutor, federal prosecutor, brigade judge advocate, administrative law attorney, legal assistance attorney, and military magistrate while he was a judge advocate. As an Army judge advocate, Prof. Cox completed the Special Victims Unit Investigations Course at the U.S. Army Military Police School as well as the Intermediate Trial Advocacy Course and the Brigade Leader's Course at the U.S. Army Judge Advocate General's Legal Center and School, among other professional certification courses.
} 


\section{Measuring the Effectiveness of the Proposal to Divest Military Commanders of Disposition Authority for Sexual Assault Cases: A Comparative Quantitative Analysis}

As the Independent Review Commission (IRC) continues the assigned 90-day assessment of the issue of sexual assault in the U.S. military, ${ }^{1}$ the topic of military justice reform has returned to center stage in the American political landscape. Among the most contentious debates that has come to the fore yet again is whether military commanders should retain the authority to refer allegations of sexual assault to court-martial. Although this suggested reform is characterized by critics as a "solution in search of a problem,"2 by now this perennial high-profile target for avowed reformists has created a "dysfunctional cycle" that has been attributed to a "lack of basic knowledge about the military justice system." 3

One centerpiece in the campaign for reform is to paint a damning picture of sexual assault in the military by crafting a convincing narrative that is founded on a statistical analysis. However, basing qualitative policy reforms, such as "improving" the problem of sexual assault in the military, primarily on statistical data carries a significant risk that the changes may not achieve the desired effect since numerical data is often not particularly revealing regarding the underlying causes of the particular quantitative conditions being measured. Nonetheless, the quantitative data that is available to the public has become a centerpiece of the widespread characterization of the dire state of the U.S. military justice system and the resulting need for drastic reform.

As but one recent example, Senator Kirsten Gillibrand pointed out in a PBS interview, "Not only are there 20,000 estimated sexual assaults each year, but the percentage of cases that are going to trial is going down, and the percentage of cases ending in

\footnotetext{
${ }^{1}$ See Deputy Sec'y Def. Memorandum, Independent Review Commission on Sexual Assault in the Military Structure and Membership (Mar. 23, 2021), https://media.defense.gov/2021/mar/24/2002607579/-1/1/0/independent-review-commission-on-sexual-assault-in-the-military-structure-and-membership.pdf. ${ }^{2}$ Geoffrey S. Corn, Chris Jenks \& Timothy C. MacDonnell, A Solution in Search of a Problem: The Dangerous Invalidity of Divesting Military Commanders of Disposition Authority for Military Criminal Offenses, JUST SECURITY (June 29, 2020), https://www.justsecurity.org/71111/introducing-an-open-letter-from-former-u-s-militarycommanders-judge-advocates-commander-authority-to-administer-the-ucmj.

${ }^{3}$ Chris Jenks \& Geoffrey S. Corn, The Military Justice "Improvement" Act of 2020, CAAFLOG 1 (July 15, 2020), https://www.caaflog.org/home/profs-jenks-corn-caaflog-exclusive-re-mjia.
} 
conviction is also going down." "This quantitative narrative was cited to support Gillibrand's assertion that the "epidemic of sexual assault" in the military "is getting much worse." This characterization by Senator Gillibrand is strikingly similar to an assertion presented in the forum of public advocacy that the U.S. military is in the grips of an "epidemic of rape."5 Setting aside the efficacy of statistics-based narratives for the moment, the matter of whether the proposed reform would achieve the desired outcome is still a matter of debate. As Professor Lesley Wexler recently observed, an enhanced empirical or theoretical focus on jurisdictions that do not utilize a commander-centric model can help "make sure that the reforms proposed both address the existing problems and don't exacerbate them unintentionally or create new ones altogether." ${ }^{6}$ The chairperson of the IRC, Lynn Rosenthal, has maintained that the Commission is committed to considering "major shifts and big picture items" designed to "bring about evidence-based prevention and hold offenders accountable." ${ }^{\prime 7}$ However, a detailed quantitative study of jurisdictions that have already divested commanders of the authority to refer sexual assault cases to trial should accompany any purported evidence-based suggestion for a "major shift" in policy in order to ensure that the "reform" is likely to have the desired effects.

This essay assesses the performance of several U.S. partners and allies in relation to preventing and responding to sexual assault in the military. In doing so, the study is designed to contribute to the endeavor of developing an enhanced empirical and theoretical focus on jurisdictions that do not implement a commander-centric model of referring sexual assault cases to court-martial. The intent is to inform judgments regarding whether the proposed reform would actually be expected to address the existing problems and improve performance if implemented by the U.S. military.

\footnotetext{
${ }^{4}$ Sen. Gillibrand: Sexual Assault in Military an 'Epidemic' That's Getting Worse, PBS NewsHour (Mar. 24, 2021), https://www.pbs.org/newshour/show/sen-gillibrand-sexual-assault-in-military-an-epidemic-thats-getting-worse.

${ }_{5}^{5}$ Press Release, Protect Our Defenders \& Military Sexual Assault Survivors Announce Launch of 2020 Senate Candidate Pledge to Help End Crisis of Military Sexual Assault, PROTECT Our DEFENDERS (Oct. 8, 2020), https://www.protectourdefenders.com/press-release-protect-our-defenders-military-sexual-assault-survivorsannounce-launch-of-2020-senate-candidate-pledge-to-help-end-crisis-of-military-sexual-assault.

${ }^{6}$ Lesley Wexler, Military \#MeToo Justice: Is a Change Going to Come?, VeRDICT (Apr. 13, 2021), https://verdict.justia.com/2021/04/13/military-metoo-justice-is-a-change-going-to-come.

${ }^{7}$ C. Todd Lopez, Commission Begins 90-Day Look Into Sexual Assault in Military, DOD News (Mar. 24, 2021), https://www.defense.gov/Explore/News/Article/Article/2548632/commission-begins-90-day-look-into-sexualassault-in-military.
} 
While care must be taken to account for historical and cultural divergences when comparing legal frameworks across jurisdictions, analyzing the performance of jurisdictions that are similar in heritage to the United States but that do not permit commanders to refer sexual assault cases to trial can provide valuable insight regarding whether the proposed reform would achieve the desired effect. Because the U.S. military currently vests in commanders the authority to refer all criminal cases to court-martial, there is no data from which to draw to develop an assessment of the projected effectiveness of the suggested reform. In the absence of conclusive evidence at home to support or refute the effectiveness of the proposal, what lessons can be gleaned from abroad?

\section{Developing the Factors by Which to Measure "Success"}

To provide analytical structure to this question, this study draws on two salient observations on the topic that can be attributed to Senator Gillibrand. To establish the selection of jurisdictions to consult, a page on Gillibrand's current website that is dedicated to the Military Justice Improvement Act notes that representatives from four other jurisdictions - Australia, the United Kingdom, Israel, and Canada - provided evidence involving their own domestic military justice system to a Senate hearing in $2013 .{ }^{8}$ These four jurisdictions, then, are selected as the comparison set for the present inquiry.

Next, to develop a desired endstate, this study returns to Gillibrand's recent PBS interview for a particularly comprehensive articulation of what she hopes to achieve by pursuing this reform. During the interview, Senator Gillibrand asserted that if the "decision whether or not to go to trial in a given case [is] given to a trained military prosecutor who's outside of the chain of command of the victim and the accused": 9

Then survivors would know that there was someone who would look at their case who

has no skin in the game, who has no bias, who doesn't know them or the accused, who

\footnotetext{
${ }^{8}$ Kirsten Gillibrand, Military Justice Improvement Act: Comprehensive Resource Center for the Military Justice Improvement Act, https://www.gillibrand.senate.gov/mjia (last visited May 21, 2021).

${ }^{9}$ PBS NEwsHour, supra note 4.
} 
will give them a fair shake. It will mean more survivors come forward. And it will also mean that, because of that professionalism, perhaps different cases are chosen and there's a better end result.

Based on separate comments during the PBS interview, during which Senator Gillibrand asserts that "unfortunately, the problem is getting much worse" given that there are " 20,000 estimated sexual assaults each year," it is reasonable to incorporate an expectation of reduced incidence of sexual assault in the military to the list of desired outcomes as well.

With this vision in mind for what it would look like to, in Senator Gillibrand's words during the interview, "fix this problem," it would be reasonable to expect that the jurisdictions to which Gillibrand's website refers - Australia, the United Kingdom, Israel and Canada - demonstrate acceptable performance in the categories of desired improved outcomes. This would support the conclusion that the United States could expect similar progress if it were to follow suit and "professionalize how the armed services handle[s]" sexual assault cases. That is, if "fixing" the problem means reduced incidence of reports of sexual assault, more victims coming forward, different cases being chosen, and a better end result for sexual assault cases (given remarks from earlier in the interview, presumably "better" in this context means higher conviction rates), observing these outcomes in the comparison set would constitute very strong evidence indeed in support of the proposal.

Unfortunately for reformists, a comparative analysis reveals quite the opposite in relation to all of the categories of desired improved outcomes. In fact, an assessment of the current state of each of the four jurisdictions selected for the present inquiry demonstrates that there is no correlation at all - let alone indications of a causal relationship - between the proposed reform and improved outcomes involving sexual assault cases. The absence of at least a correlative relationship suggests that the proposed reform is unlikely to be effective in achieving the desired outcomes and that different measures may be called for.

Although a full description of all potential comparative factors is beyond the scope of this study, an overview of the relevant aspects of the military justice structures of each of the four identified jurisdictions is sufficient for the present purpose of demonstrating the lack of 
a correlative relationship between the proposed reform and the desired outcomes. After briefly introducing the military justice system in each jurisdiction, the analysis in the next section presents a snapshot of current discourse involving sexual assault in the military for each. Following the comparative analysis in the next section, this study concludes with some reflections on the forthcoming report of the Independent Review Commission.

\section{Brief Introduction and Overview of Current Relevant Discourse in the Four Selected Jurisdictions}

Australia

The military justice system in Australia is centered on the Defence Force Discipline Act of 1982, the present compilation of which (No. 33) is current as of March 2, 2019.10 While the Australian MJ system does permit military commanders to refer certain cases to court-martial, commanders may not do so in the case of a "prescribed offence." These include some specified offenses such as treason, murder, and manslaughter, ${ }^{11}$ while the Defense Force Discipline Regulations further define prescribed offences as a service offence that is punishable by imprisonment for more than two years. ${ }^{12}$

For any prescribed offence, a commander or military law enforcement agency may refer a file to the Director of Military Prosecutions (DMP), and the DMP determines whether to initiate a court-martial. Likewise, if an agency of the Joint Military Police Unit (JMPU) determines that a case involving prescribed offences should not go forward, the JMPU agrees to refer the file to the Office of the DMP (ODMP) "for consideration as to the appropriate course of action to be taken."13 According to $\S 63$ of the DFDA, the (civilian) Director of Public Prosecutions must provide consent before the ODMP may

\footnotetext{
${ }^{10}$ See Defence Force Discipline Act 1982 (Cth), https://www.legislation.gov.au/details/c2019c00107.

${ }^{11}$ Defence Force Discipline Regulations 2018 (Cth) $\$ 104$ https://www.legislation.gov.au/details/f2018100265

${ }^{12} I d$., $\S 51$ (this section of the DFDA includes a few exceptions to the definition of prescribed offenses that are not relevant to the present discussion).

${ }^{13}$ Director of Military Prosecutions, Report for the Period 01 January to 31 December 2019 (3 April 2020), para 37, https://www.defence.gov.au/mjs/docs/2019-dmp-annual-report.pdf.
} 
initiate a prosecution for "certain serious offences, such as murder and aggravated sexual assault offences." 14

Although the ODMP commenced operations in July 2003, ${ }^{15}$ the Defence Legislation Amendment Act of 2006 consolidated the previous system of convening authorities and conferred the role of primary convening authority to the DMP. ${ }^{16}$ Because the ODMP refers prescribed offences to court-martial, then, military commanders do not have charging authority in relation to allegations of serious sexual misconduct. Since data involving the annual number of allegations of sexual misconduct is not available from before 2006 when the ODMP assumed primary consolidated convening authority for prescribed offences, a simple comparison of pre-reform and post-reform statistics is not possible. However, a statistical analysis of several key data points is useful in the endeavor to assess whether moving primary charging authority from commanders to the DMP enhanced the performance of the Australian military justice system in relation to the categories of outcomes reformists in the United States hope to improve by following suit.

The first point of interest is to note that there is no statistical correlation between the reform and the numbers of reports of "unacceptable behavior" that were submitted during the relevant time period. This metric, unacceptable behavior, which includes sexual offenses among other similar categories of misconduct, is the only quantifiable data set that spans the pre-reform and post-reform period. Starting with the period of 2001-2002 and continuing through the period of 2010-11, the total number of reports of unacceptable behavior per year are: $331,451,586,749,685,846,765,873,719$, and 720 (these figures are drawn from three consolidated reports, the Defence Annual Reports of 2004-05, ${ }^{17} 2008-09,{ }^{18}$ and 2010 $\left.11^{19}\right)$. The fifth entry in this data set of ten annual figures, 685 , corresponds with the year DMP assumed primary consolidated convening authority for the Australian Defence Force.

\footnotetext{
${ }^{14} I d$. para. 54.

${ }^{15}$ Department of Defence, Annual Report 2004-05 (4 November 2005), 125, https://www.defence.gov.au/annualreports/04-05/downloads/0405_dar_10_full.pdf.

${ }_{16}^{16}$ See Defence Legislation Amendment Act 2006 (Cth), https://www.legislation.gov.au/details/c2006a00159.

${ }^{17}$ Department of Defence, supra note 15 at 121.

${ }^{18}$ Department of Defence, Annual Report 2008-09, Vol. 1, cover 2 (Table, Key Defence Statistics), https://www.defence.gov.au/AnnualReports/08-09/2008-2009_Defence_DAR_01_v1prelim.

${ }^{19}$ Department of Defence, Annual Report 2010-11, Vol. 1 at 265 (Figure A5.3), https://www.defence.gov.au/AnnualReports/10-11/dar_1011_v1_full.pdf.
} 
If a measure of performance for the military justice system is that the number of reports of unacceptable behavior will decline, these statistics indicate that there is not a correlation between the reform and this measure of performance. Although "unacceptable behavior" in this context is not limited only to sexual offenses, the perceived performance of the ADF involving certain "aspects of military and organisational culture," including "in relation to sexual and other abuse," prompted a series of comprehensive reviews beginning in $2011^{20}$ (the end of the above data set). If satisfactory progress had been made from 2006 to 2011, it would be reasonable to assume that "sexual and other abuse" would not have been an "aspect of military and organisational culture" that needed to be reviewed.

A second point of interest related to ADF statistical reports is that the number of reports of sexual assault incidents has not appreciably declined in the period ranging from 2012-13 to 2019-20. While this range does not date back to 2006 when DMP took over primary convening authority for courts-martial, it is again reasonable to assume that pre2012 statistical measurements were deemed to be unacceptable at least as late as 2011 when the wave of comprehensive reviews related to military and organizational culture was directed. The benefit of the data set reflected in the table below, which is drawn from the 2019-20 installment of the Annual Defence report, ${ }^{21}$ is that the statistics present the numbers of reported sexual assaults per reporting period rather than reports of "unacceptable behavior" more generally.

Although the figures from 2016-17 and before cannot be compared directly with the figures from 2017-18 and later since "different reporting frameworks" were adopted starting in 2017, this data set presents no indication that the number of reported sexual assault incidents per year has declined appreciably since at least 2012:

Table 6.28: Reported Defence sexual assault incidents per year

\begin{tabular}{|c|c|c|c|c|c|c|c|}
\hline \multicolumn{5}{|c|}{ Model Criminal Code } & \multirow{2}{*}{$\begin{array}{l}\text { ANZSOC } \\
2017-18\end{array}$} & \multirow{2}{*}{$\begin{array}{l}\text { ANZSOC } \\
2018-19\end{array}$} & \multirow{2}{*}{$\begin{array}{l}\text { ANZSOC } \\
2019-20\end{array}$} \\
\hline $2012-13$ & 2013-14 & 2014-15 & $2015-16$ & $2016-17$ & & & \\
\hline 60 & 96 & 98 & 84 & 87 & 170 & 166 & 161 \\
\hline
\end{tabular}

\footnotetext{
${ }^{20}$ See Department of Defence, Annual Report 2010-11, Part 1 at 4, https://www.defence.gov.au/annualreports/1112/dar_1112_full.pdf.

${ }^{21}$ Department of Defence, Annual Report 2019-20 (21 September 2020), 143, https://www.defence.gov.au/annualreports/19-20/dar_2019-20_complete.pdf.
} 
A third point of interest that emerges from examining the various reports that are available to the public and that involve metrics of sexual assault in the ADF is that the number of new incident management advice clients that are reported by the Sexual Misconduct Prevention and Response Office (SeMPRO) has increased steadily since the Office began operations in July 2013. The table below, which is drawn from the most recent annual SeMPRO report, reveals that the average number of new incident management advice clients referred to SeMPRO in the office's first three years of operation was 116, while the average number in the three most recent years is $251.30 .{ }^{22}$ This represents a more than twofold increase in the average number of new incident management advice clients that were referred to the Sexual Misconduct Prevention and Response Office in the most recent three years as compared to its first three years of operations.

Table 3: Sexual Misconduct Prevention and Response Office new incident management advice clients 2013-14 to 2019-20.

\begin{tabular}{|l|l|}
\hline Financial year & Number of SeMPRO advice clients \\
\hline $2013-14$ & 70 \\
\hline $2014-15$ & 147 \\
\hline $2015-16$ & 131 \\
\hline $2016-17$ & 223 \\
\hline $2017-18$ & 253 \\
\hline $2018-19$ & 266 \\
\hline $2019-20$ & 235 \\
\hline Total & 1,325 \\
\hline
\end{tabular}

The final point of interest involving reports of sexual assault in the ADF to be addressed here involves the prevalence of complainants in sexual offense allegations who make the informed decision not to participate in investigative or prosecutorial efforts. In the most recent report published by the Director of Military Prosecutions, the DMP explains in detail the process and purpose of the dialogue in which the prosecution engages with the complainant in a sexual assault allegation: ${ }^{23}$

Complainants in sexual offence allegations are advised of all their options, the legislative protections provided for them, including giving evidence remotely, restriction on cross examination and suppression of complainant's identity and the fact

\footnotetext{
${ }^{22}$ Sexual Misconduct Prevention and Response Office Annual Report FY 2019-20, 16, https://www.defence.gov.au/sempro/_master/docs/sempro-annual-report-fy2019-20.pdf.

${ }^{23}$ Director of Military Prosecutions, supra note 13, para. 42.
} 
that they can reverse their decision not to proceed with an allegation at a later date and the implications that may bring. The intention is to ensure that a complainant's decision not to proceed any further with a complaint is not based on erroneous assumptions or misunderstanding about the prosecution process.

Notwithstanding this detailed dialogue that is designed to ensure that complainants make an informed decision whether to participate in the prosecutorial process, this most recent DMP report indicates, "As in the previous reporting period, the overwhelming majority of [cases referred to ODMP] were prescribed sexual offences," and "in the majority of cases, the complainant made the informed decision to take no further action once the complaint was made, or there was insufficient credible evidence to proceed with the matter." ${ }^{24}$ With the above data related to the issue of sexual assault in the military in focus, what lessons can be drawn regarding the intended outcomes if the suggestion to remove prosecution decisions from military commanders were to be implemented in the United States?

If the overall number of reports of sexual offenses is any indication of the effectiveness of the reform, the above analysis presents no correlative relationship to suggest that implementing the reform would reduce the number of allegations of sexual assault made each year. The connection between the sharp and steady rise of new incident advice clients referred to SeMPRO each year and the observation by the DMP that a complainant makes an informed decision not to proceed with the prosecution process is a factor "in the majority of cases" indicates that there is no correlation to support the assertion that conferring courtmartial convening authority outside the chain of command "will mean more survivors come forward" if the suggested reform were implemented in the United States. The other factor that contributes to the DMP observation that an allegation does not progress "in the majority of cases" - that "there was insufficient credible evidence to proceed with the matter" - indicates that conferring convening authority to a prosecutor rather than a commander will not mean "different cases are chosen and there's a better end result."

\footnotetext{
${ }^{24} I d$, para. 38 .
} 
In short, an analysis of the performance of the ADF military justice system presents no correlative relationship to support the assertion that the suggested reform will "fix" the problem of sexual assault in the military if the United States were to follow Australia's lead.

\section{The United Kingdom}

The United Kingdom established an independent military prosecution service in 2006. For the UK, the revision was primarily in response to a string of successful challenges filed with and adjudicated by the European Court of Human Rights. In the first such case, Findlay v. United Kingdom (1997), the ECtHR found that the degree of authority exercised by the accused's commander violated the accused's/complainant's right to an independent trial pursuant to Article 6(1) of the European Convention on Human Rights. ${ }^{25}$ After several similar decisions by the ECtHR (such as Coyne (1997), ${ }^{26}$ Morris (2002), ${ }^{27}$ and Grieves (2003) ${ }^{28}$ ), the UK finally established the independent Service Prosecuting Authority (SPA) with the adoption of the Armed Forces Act of 2006. ${ }^{29}$

In the UK, the SPA "is the principal prosecuting authority within the Service Justice System and is responsible for the prosecution of service offences before the Service Courts." 30 The primary functions of the SPA are to decide "whether the case should be prosecuted," decide "where the case should be prosecuted," determine "the appropriate charges to bring," and to prepare and present cases "in the Service courts - using either employed advocates or members of the Bar." 31 As the SPA main website notes, the office "is

\footnotetext{
${ }^{25}$ See Findlay v. United Kingdom, App. No. $22107 / 93$ (Feb. 25, 1997), https://hudoc.echr.coe.int/eng\#\{\%22itemid\%22:[\%22001-58016\%22]\}. ${ }^{26}$ See Coyne v. United Kingdom, App. No. 25942/94 (Sep. 24, 1977), https://hudoc.echr.coe.int/eng\#\{\%22itemid\%22:[\%22001-58097\%22]\}.

${ }^{27}$ See Morris v. United Kingdom, App. No. 38784/97 (Feb. 26, 2002), https://hudoc.echr.coe.int/eng\#\{\%22fulltext\%22:[\%22morris\%20v.\%20uk\%22],\%22documentcollectionid2\%22:[\% 22GRANDCHAMBER\%22,\%22CHAMBER\%22],\%22itemid\%22:[\%22001-60170\%22]\}.

${ }^{28}$ See Grieves v. United Kingdom, App. No. 57067/00 (Dec. 16, 2003), https://hudoc.echr.coe.int/eng\#\{\%22tabview\%22:[\%22document\%22],\%22itemid\%22:[\%22001-61550\%22]\}.

${ }^{29}$ See Armed Forces Act 2006, https://www.legislation.gov.uk/ukpga/2006/52/part/18/crossheading/serviceprosecuting-authority.

${ }^{30}$ Ministry of Defence, Guidance: Service Prosecuting Authority, https://www.gov.uk/guidance/service-prosecutingauthority (Feb. 24, 2021).

${ }^{31} I d$.
} 
independent of both the Ministry of Defence and the military chain of command in respect of its prosecutorial functions," and it "acts under the general superintendence of the Attorney General." 32

Although the breadth and depth of statistical reporting for the UK does not quite match the Australian example, the nature of reporting adequately supports the endeavor of the UK government to measure the performance of the military justice system. While the most extensive and consistent statistical reporting dates back only to 2015, a number of trends that are relevant to the present inquiry emerge from an assessment of a few key metrics. The table below collects several data points from the 201733 and $2020^{34}$ editions of the annual report known as the Sexual Offences in the Service Justice System.

Since each annual report presents data from the current and preceding two years, an analysis of these two reports permits coverage from 2015 to 2020. For the present inquiry, the following data points related to allegations of sexual offenses are drawn from these two reports: number of military personnel suspected of committing sexual offenses (Table 2 of the reports), number of cases referred to the SPA for possible prosecution (Table 5 of the reports), number of offenses with defendants heard at courts-martial (Table 6), and number of guilty verdicts for these courts-martial (also Table 6). From 2015 to 2020, the numbers for each data point in the set, as well as the percent of cases referred to the SPA that were heard at court-martial and the percent of convictions for these cases at court-martial, are:

\footnotetext{
${ }^{32} \mathrm{Id}$.

${ }^{33}$ Ministry of Defence, Sexual Offences in The Service Justice System: 2017, https://www.gov.uk/government/statistics/sexual-offences-in-the-service-justice-system-2017 (MS Excel Spreadsheet) (Mar. 20, 2019).

${ }^{34}$ Minisry of Defence, Sexual Offences in The Service Justice System: 2020, https://www.gov.uk/government/statistics/sexual-offences-in-the-service-justice-system-2020 (MS Excel Spreadsheet) (Mar. 25, 2021).
} 


\begin{tabular}{|l|l|l|l|l|l|l|l|}
\hline & $\mathbf{2 0 1 5}$ & $\mathbf{2 0 1 6}$ & $\mathbf{2 0 1 7}$ & $\mathbf{2 0 1 8}$ & $\mathbf{2 0 1 9}$ & $\mathbf{2 0 2 0}$ & Total \\
\hline Military suspects & 88 & 116 & 138 & 160 & 188 & 150 & 840 \\
\hline Cases referred to SPA & 99 & 130 & 86 & 123 & 157 & 152 & 747 \\
\hline $\begin{array}{l}\text { Offenses with defendants } \\
\text { heard at court-martial }\end{array}$ & 51 & 47 & 70 & 55 & 58 & 50 & 331 \\
\hline Guilty verdicts & 21 & 21 & 26 & 21 & 16 & 29 & 134 \\
\hline $\begin{array}{l}\text { Percent of referrals heard } \\
\text { at court-martial }\end{array}$ & 51.5 & 36.2 & 81.4 & 44.7 & 36.9 & 32.9 & 44.3 \\
\hline $\begin{array}{l}\text { Percent of convictions } \\
\text { from courts-martial }\end{array}$ & 41.1 & 44.7 & 37.1 & 38.1 & 27.6 & 58.0 & 40.5 \\
\hline
\end{tabular}

If these figures are compared to similar data drawn from reports published by the U.S. military, an analytical comparison of the number of cases referred to court-martial and the number of convictions at trial can be performed. Since military commanders rather than an independent prosecutor refer cases to trial in the U.S. system, the number of alleged sexual offenses for which the evidence supports a potential commander's action (rather than the SPA) takes the place of the second row above. Also, because statistics are compiled by the U.S. military by fiscal year, which ends on September 30, the FY20 report is not yet available.

The data in the top row in the table below is drawn from the U.S. 2019 Annual Report on Sexual Assault in the Military (commonly referred to as a SAPRO Report) by extrapolating the percentage of sexual offenses for which a service member is a suspect from the total number of reported offenses for each year. ${ }^{35}$ The remaining figures are drawn from a statistical study that collects the relevant data from the corresponding SAPRO Reports for each year. ${ }^{36}$ The following table, then, presents for the U.S. military the data that is equivalent to entries related to the UK military justice system reflected in the table above.

\footnotetext{
${ }^{35}$ Dep't Def., Annual Report on Sexual Assault in the Military, Fiscal Year 2019 (Apr. 17, 2020), Appendix B at 11 (Figure 4), https://www.sapr.mil/sites/default/files/3 appendix_b_statistical_data_on_sexual_assault.pdf.

${ }^{36}$ David A. Schlueter \& Lisa M. Schenck, National, Military, and College Reports on Prosecution of Sexual Assaults and Victims' Rights: Is the Military Actually Safer than Civilian Society?, 56 GonZ. L. R. 285, 331 (Table 32), https://commons.stmarytx.edu/cgi/viewcontent.cgi?article=1615\&context=facarticles.
} 


\begin{tabular}{|l|l|l|l|l|l|l|l|}
\hline & $\mathbf{2 0 1 5}$ & $\mathbf{2 0 1 6}$ & $\mathbf{2 0 1 7}$ & $\mathbf{2 0 1 8}$ & $\mathbf{2 0 1 9}$ & $\mathbf{2 0 2 0}$ & Total \\
\hline Military suspects & 3,621 & 3,489 & 3,884 & 4,470 & 4,616 & -- & 20,080 \\
\hline $\begin{array}{l}\text { Evidence supports } \\
\text { commander's action }\end{array}$ & 1,437 & 1,331 & 1,466 & 1,211 & 1,629 & -- & 7,074 \\
\hline Cases tried at court-martial & 543 & 389 & 406 & 307 & 363 & -- & 2,008 \\
\hline Convictions & 413 & 261 & 284 & 203 & 264 & -- & 1,425 \\
\hline $\begin{array}{l}\text { Percent supportable } \\
\text { offenses tried at court- } \\
\text { martial }\end{array}$ & 37.8 & 29.2 & 27.7 & 25.4 & 22.2 & -- & 28.4 \\
\hline $\begin{array}{l}\text { Percent of convictions } \\
\text { from courts-martial }\end{array}$ & 76.1 & 67.1 & 70.1 & 66.1 & 72.7 & -- & 70.1 \\
\hline
\end{tabular}

In total, the rate of cases tried at court-martial is $64.1 \%$ higher in the UK as compared to the U.S., but the conviction rate for the cases that are tried by court-martial is $57.8 \%$ higher in the U.S. over this period as compared to the UK. Incidentally, the percentage of cases initiated by military commanders in the US over this period is $55.9 \%$, which is slightly higher than the $44.3 \%$ of referrals to the SPA in the UK that are heard at court-martial. The higher rate of initiation (55.9\%) compared with the lower rate of cases ultimately tried at court-martial in the U.S. $(28.4 \%)$ indicates that a significant number of cases $(1,946$ over five years) are determined by commanders not to be appropriate for courtmartial during the pre-trial process or are resolved prior to trial. For both jurisdictions, the number of reports for which a service member is the subject has gradually increased over this period of time.

While the rate of cases heard at court-martial is notably lower for the U.S. military, the conviction rate for those cases that $d o$ go to trial is substantially higher in the U.S. system. Likewise, the rate of cases for sexual offenses are initiated by U.S. commanders is noticeably higher than the rate of cases ultimately sent to court-martial by the SPA in the UK. If the figures from the UK present a useful comparison, the statistical analysis of similar U.S. and 
UK numbers indicates that the U.S. is already performing in a similar or even preferrable manner as compared to a military justice system that has conferred court-martial convening authority to an independent Service Prosecution Authority since 2006.

Israel

The military justice system for the Israel Defense Forces (IDF) is similar to the UK in that a military prosecutor is conferred with the sole authority to refer a case to court-martial (to "draw up and file informations" in the vernacular of the Military Justice Law). ${ }^{37}$ When current law professor and former IDF judge advocate Amos N. Guiora gave testimony to the U.S. Senate in 2013, he observed that the "the Israeli system is profoundly different from the current American system" primarily because of the " "balance of power' between the commander and the Judge Advocate." 38 As a judge advocate, Guiora noted, he "was solely entrusted with the decision to order the filing of an indictment against a soldier or officer" and "the commander was granted no authority in the matter." 39

Although primary sources containing metrics such as those examined above for other jurisdictions are not as widely available to the public (as far as I can tell), some relevant and useful data is available from secondary sources. Regarding the overall number of sexual assault complaints filed by military members, a report released last year observed that "in the last decade there has been an average annual increase of 11 percent in reports." ${ }^{40}$ According to the same report, the number of complaints filed last year alone constitutes an "exceptional increase in scope" compared to the previous year since the increase in 2020 was $24 \%$ compared to 2019 - which is of course far higher than the average annual increase of $11 \% .{ }^{41}$

\footnotetext{
37 § 181(b), Military Justice Law, 5715-1955, SH 189 171, as amended, http://www.knesset.gov.il/review/data/eng/law/kns2_militaryjustice_1_eng.pdf.

${ }_{38}$ Pending Legislation Regarding Sexual Assaults in the Military: Hearing Before the S. Comm. on Armed Services, 130th Cong. 219 (2013) (statement of Amos N. Guiora), https://www.congress.gov/113/chrg/CHRG113shrg88639/CHRG-113shrg88639.pdf\#page=223 [hereinafter Statement of Amos N. Guiora].

${ }^{39}$ Id.

${ }^{40}$ IDF Chief: 'Zero Tolerance' for Officer-Subordinate Relationships, THE TIMES OF ISRAEL (Feb. 25, 2021), https://www.timesofisrael.com/idf-chief-zero-tolerance-for-officer-subordinaterelationships/\#: :text=Israel\%20Defense \%20Forces\%20Chief\%20of,vowing\%20to\%20root\%20them\%20out. ${ }^{41} I d$.
} 
A similar report published in 2019 found that 1,706 complaints involving sexual offenses were received from military members, while "just 165 cases were investigated by the relevant military authorities." 42

This represents an investigation rate of $9.7 \%$. The seemingly low rate of investigation is consistent with a description of the findings of a similar report from 2018. According to the description of these official findings, while "soldiers are more comfortable reporting sexual assault, the report found there has been almost no increases in investigations by military police into sexual assaults reported by soldiers and even a drop in cases opened by the Military Advocate General's Office.”43

Based on the overall number of complaints related to sexual offenses that are filed by military members, then, the current trend in Israel is the same as in Australia and the UK: a steady annual increase during the past several years. Notwithstanding this steady increase in the number of complaints filed, the number of investigations initiated and cases prosecuted appears to be trending in the opposite direction. This is the case even though, to return to Guiroa's reflection in 2013, "the Israeli system is profoundly different from the current American system" in that judge advocates are "solely entrusted with the decision to order the filing of an indictment against a soldier or officer." 44

\section{Canada}

For the Canadian Armed Forces (CAF), the authority to send a criminal charge to court-martial (that is, "prefer" charges in CAF vernacular) is vested solely with the Canadian Military Prosecution Service (CMPS), ${ }^{45}$ for which the Director of Military Prosecutions (DMP) is the head. The recommendation to establish this separate prosecution service was a

\footnotetext{
429 Out of 10 Rape Cases in Israel Closed Without Charges - Study, THE TIMES OF ISRAEL (Nov. 20, 2019), https://www.timesofisrael.com/9-out-of-10-rape-cases-in-israel-closed-without-charges-study.

${ }^{43}$ Anna Ahronheim, Dramatic Rise in Number of IDF Soldiers Reporting Sexual Assault, THE JERUSALEM POST (Nov. 20, 2018), https://www.jpost.com/israel-news/dramatic-rise-in-number-of-idf-soldiers-reporting-sexualassault-572369.

${ }^{44}$ Statement of Amos N. Guiora, supra note 38 at 219.

${ }^{45}$ Director of Military Prosecutions, Annual Report 2019-20 at 1 (23 June 2020), https://www.canada.ca/content/dam/dnd-mdn/documents/legal-juridique/reports-rapports/dmp-dpm/dmp-ar-201920-en.pdf.
} 
central aspect of the 1997 Report of the Special Advisory Group on Military Justice. ${ }^{46}$ The CMPS as well as the position of DMP have been operational since September 1999.

In 2015, an external review of the Canadian military justice system observed that "very little data is collected by the CAF with respect to the occurrence of either sexual harassment or sexual assault." 47 This review, which is widely referred to as the Deschamps Report (after the external review authority, Marie Deschamps), further determined that "the failure to keep data on complaints of sexual assault significantly weakens the accountability of the chain of command."48 Largely as a result of these findings, starting in 2016 there are now more extensive and comprehensive statistical data available for study.

The first data point to be considered here appears at first glance to be encouraging if a desired outcome is a reduction in the number of reported sexual assaults. During the threeyear period from FY 2016-17 to FY 2018-19, the number of sexual assault incidents reported to the chain of command fell from 461 to 413 to $302 .{ }^{49}$ This constitutes a steady and rather impressive decline of $65.5 \%$ over a three-year period.

However, when these figures are considered in light of statistics involving responses to a biennial survey, the performance of the CAF related to the desired outcomes if the United States were to divest commanders of court-martial referral authority appears rather less encouraging. In the first such survey, which was administered externally by Statistics Canada in 2016, a total of 960 CAF Regular Force members indicated that they had experienced sexual assault during the 12 months before completing the survey. ${ }^{50}$ In the second survey, which was administered by Stats Canada in 2018, that same figure fell a meager $7 \%$, to 900 total. 51

\footnotetext{
${ }^{46}$ See Director of Military Prosecutions, GOVERNMENT OF CANADA, https://www.canada.ca/en/department-nationaldefence/services/benefits-military/legal-services/mil-prosecutions.html (last visited May 23, 2021).

${ }^{47}$ Marie Deschamps, External Review into Sexual Misconduct and Sexual Harassment in the Canadian Armed Forces at vi (Mar. 27, 2015), https://www.canada.ca/content/dam/dndmdn/migration/assets/forces_internet/docs/en/caf-community-support-services-harassment/era-final-report-april-202015-eng.pdf.

${ }^{48}$ Id. at 72 .

492019 Sexual Misconduct Incident Tracking Report 4 (August 2019), https://www.canada.ca/content/dam/dndmdn/documents/reports/2019/2019-sexual-misconduct-report-en.pdf.

${ }^{50}$ Sexual Misconduct in the Canadian Armed Forces, 2016, STATISTICS CANADA 11 (28 November 2016), https://www150.statcan.gc.ca/n1/en/pub/85-603-x/85-603-x2016001-eng.pdf?st=ZOh5OnSw.

${ }^{51}$ Sexual Misconduct in the Canadian Armed Forces, 2018, STATISTICs CANADA 11 (22 May 2018), https://www150.statcan.gc.ca/n1/en/pub/85-603-x/85-603-x2019002-eng.pdf?st=fXoKV9aD.
} 
In the first iteration of the Statistics Canada survey, the number of reports of sexual assault received by the chain of command is $48.0 \%$ lower than the number of respondents who indicated that they experienced sexual assault over a comparable period (461 reports to the command compared to 960 affirmative survey responses). By the time of the second survey, that percentage fell to $33.6 \%$ (302 reports to 900 affirmative survey responses). These data points reveal that five years ago almost half of the Regular Force members who indicated that they had been the victim of sexual assault declined to make a report, while three years ago the rate of reporting fell from about half to only one third.

According to Senator Gillibrand's performance criteria, this already low reporting rate and the subsequent sharp decline would indicate a lack of trust in the reporting and adjudication process in the CAF. This condition exists notwithstanding that statutory courtmartial preferral authority ("referral" in U.S. military vernacular) has been vested solely in the Director of Military Prosecutions since 1998. ${ }^{2}$ When the rate at which allegations of sexual assault that do get reported to the chain of command are preferred to court-martial (again, a "preferral" in CAF terminology is a "referral" in U.S. vernacular), the apparent performance in relation to the desired outcomes if the United States were to implement the suggested reform is similarly unpromising.

In the three-year period from 2016-1753 to $2018-19,5^{4}$ the number of sexual assault offenses prosecuted at court-martial was 9, 9, and 6, respectively. As described above, the number of reports of sexual assault of which the chain of command was notified during these years was 461,413 , and 302 . The rate of court-martial preferral for sexual assault offenses as a function of the number of reports received by the chain of command each year over this three-year period, then, is $2.0 \%, 2.2 \%$, and $2.0 \%$, respectively. By way of comparison, the ratio of reports to court-martial referrals for the U.S. military during this

\footnotetext{
${ }^{52}$ National Defence Act, S.C. 1998, C 25 § 165, https://parl.ca/DocumentViewer/en/36-1/bill/C-25/royalassent/page-77\#19.

${ }^{53}$ Minister of National Defence, 2017-2018 Annual Report of the Judge Advocate General, Annex C, https://www.canada.ca/content/dam/dnd-mdn/documents/legal-juridique/reportsrapports/jag/jag_AnnualReport_2017-18.pdf\#page=56.

${ }^{54}$ Minister of National Defence, 2018-2019 Annual Report of the Judge Advocate General, Annex B, https://www.canada.ca/content/dam/dnd-mdn/documents/legal-juridique/reports-rapports/jag/jag-annual-report2018-19-en-full.pdf\#page=61.
} 
period was 3,489:389; 3,884:406; and 4,470:307 (as described in the table above when comparing the quantitative performance of the UK and the U.S.). These ratios equate to $11.1 \%, 10.5 \%$, and $6.9 \%$, respectively.

The three-year average of the ratio of the number of sexual assault notifications provided to the chain of command to the number of sexual assault preferrals/referrals during this period is $2.1 \%$ for the CAF and $9.5 \%$ for the U.S. military. This means the average for the U.S. military, where commanders make the decision to refer charges to court-martial, was more than 4.5 times higher than the average for the CAF during this period. If a goal of the suggested reform is to increase the number of sexual assault allegations that get referred to trial in the U.S. military, this comparison with the Canadian Armed Forces - where the separate Directorate of Military Prosecutions makes all preferral decisions - suggests that the U.S. military is already performing significantly better than the CAF in relation to this particular measure of performance.

\section{The Comparative Quantitative Analysis and the Independent Review Commission Recommendations}

The comparative quantitative analysis conducted in the present study does not bode well for reformists such as Senator Kirsten Gillibrand who adamantly proclaim that removing court-martial charging decisions from commanders will improve the issue of sexual assault in the United States military. The military justice systems of several U.S. partners or allies have long ago partially or completely removed charging authority from commanders in favor of lawyers. Just like the United States, these partners and allies including Australia, ${ }^{55}$ the UK, ${ }^{56}$ Israel, ${ }^{57}$ and Canada ${ }^{58}$ - are still in search of effective

\footnotetext{
${ }^{55}$ Cam Wilson, Australia's Defence Forces Have Spent $\$ 50$ Million on Sexual Abuse Claims in the Past Three Years, BUSINESS INSIDER AUSTRALIA (Oct. 28, 2020), https://www.businessinsider.com.au/australias-defenceforces-50-million-dollars-sexual-abuse-claims-in-three-years-2020-10.

${ }^{56}$ Nigel Nelson, Call for Ban on Armed Forces Trying Rape Cases after Being 'Repeatedly Bungled', MIRROR (Feb. 14, 2021), https://www.mirror.co.uk/news/politics/call-ban-armed-forces-trying-23499385.

${ }^{57}$ Zero Tolerance, supra note 40.

${ }^{58}$ Jacques Gallant, 'Are They Going to Follow Up This Time?': Ottawa Announces Another External Review of Sexual Misconduct in the Military, THE STAR (Apr. 29, 2021),
} 
solutions. The absence of a correlative relationship between the "reform" and the desired outcomes in relation to the problem of sexual assault in the military for partners and allies indicates that implementing the change in the United States will not achieve the intended effects.

That is, if the experience of partners and allies is a useful gauge, there is no quantifiable connection between removing charging authority from commanders and improved systemic performance in relation to outcomes that have been identified by reformists as indications of improvement in relation to sexual assault in the military. Of course, just like any quantitative analysis of an inherently qualitative outcome such as "improved" performance regarding sexual assault in the military, the efficiency of the statistical evaluation conducted herein is limited to a certain degree. The endeavor of drawing useful subjective appraisals from aggregated statistical data tends to obscure much of the nuance that can best inform value judgements regarding systemic performance.

This obfuscation is even more prevalent when engaging in a comparative quantitative analysis since measuring across systems is not particularly responsive to latent divergences in history and culture that could contribute to differences in performance in the areas that are measured. Inherent limitations notwithstanding, citing to quantitative data has become a mainstay in the campaign to remove charging authority from military commanders. So, too, has the tactic of asserting that the United States should follow the lead of partners and allies that have already made the switch. If the case for "reform" is to continue to rest primarily on inherently limited quantitative and comparative claims of improved performance, a comparative quantitative analysis such as that conducted in this study can help inform the judgments of lawmakers in the coming months as well as the perspectives of the constituents they represent.

For now, all eyes will be on the report of the Independent Review Commission when it is made public - and particularly on the "accountability" line of effort portion of the report. Given that the IRC was tasked with a "90-day look into sexual assault in the

https://www.thestar.com/amp/politics/federal/2021/04/29/ottawa-announces-independent-review-of-military-andpromises-external-reporting-system-for-sexual-misconduct.html. 
military" 59 and the accountability line of effort reportedly presented to Secretary Austin an initial recommendation "that would take the responsibility of prosecuting sexual assault offenses out of commanders' hands" after only six weeks, ${ }^{60}$ it is reasonable to question whether the Commission conducted a comprehensive and impartial evaluation of the available data before offering this recommendation. In the interests of full disclosure and transparency, surely the IRC will publish a comprehensive accounting of all the evidence that was presented to the Commission and that the Commission members considered when forming the recommendations that will be presented in the final report.

As part of this accounting, it is of course reasonable to expect that the recommendations from the accountability line of effort will present convincing evidence that the suggested "reform" will bring about improved systemic performance in the U.S. military. No doubt this convincing evidence will explain why the United States military can expect improved performance in relation to the issue of sexual assault in the military notwithstanding that a comparative quantitative analysis indicates that there is no correlative relationship between removing charging authority from military commanders and the improved outcomes reformists seek to foster. In the absence of a comprehensive accounting of all evidence considered and of convincing proof demonstrating that the result will be different in the U.S. military than the experiences of partners and allies that have made the switch, lawmakers and their constituents will need to consider the IRC recommendations with a considerable degree of skepticism.

\footnotetext{
${ }^{59}$ Lopez, supra note 7.

${ }^{60}$ Jim Garamone, Leaders Discuss Initial Sex Assault Review Commission Recommendation, DoD News (May 7 , 2021), https://www.defense.gov/Explore/News/Article/Article/2600363/leaders-discuss-initial-sex-assault-reviewcommission-recommendation.
} 